\title{
HAZARDS RESULTING FROM IMPROPER BUILDING DRAINAGE SYSTEM BY THE USE OF BIM
}

\author{
Grzegorz Wrzesiński ${ }^{凶}$ \\ Institute of Civil Engineering, Warsaw University of Life Sciences - SGGW
}

\begin{abstract}
This article studies hazards arising from the improper use of dewatering methods to prevent underground parts of a building. The analyses were carried out on the example of a residential building with an underground garage. Groundwater began to appear in the underground garage, after the building was used for several years. Some protections were deployed to limit the ingress of water into the building, which proved to be ineffective. Improper use of the wells to lower the groundwater level around the building led to visible scratches on the external walls and foundation slab. The article applied building information modelling (BIM) to provide information about the analysed building and to analyse further the possible hazards arising from the drainage methods used.
\end{abstract}

Key words: dewatering process, drainage system, well, building damage, groundwater, BIM

\section{INTRODUCTION}

Intensive development of residential and office buildings in large cities is introduced on areas characterized by a high or variable groundwater table. New construction investments most often include an underground garage, which is caused by local spatial development plans. New construction projects are prepared on the basis of geological and engineering documentation which is sometimes inaccurately made and does not reflect the real subsoil conditions (Todd, 1980; Wrzesiński, 2020). In many cases, the level of groundwater is determined only at the time of measurement and is specified in the documentation as a reference level for the preparation of the construction project. This means that the impact of changes in groundwater levels is rarely taken into account in new projects. Such situations may lead to the adoption of an inappropriate technology for the execution of the object and contribute to problems during its construction (Mielcarzewicz, 1971; Zaborova \& Petrichenko, 2018). Incorrect determination of the groundwater level in the geotechnical documentation also contributes to the adoption of improper construction solutions protecting underground parts of the building in the event of a change in the groundwater level at the design stage (Matusiewicz, 2011; Patel, 2019; Thomas, Goodfellow \& Watson, 2019). While at the construction stage we are most often able to deal with the problem of high groundwater level, high groundwater level at the utilization stage of the object can generate many problems and cause numerous material damages (Matusiewicz, 2015; Koda, Matusiewicz \& Osiński, 2017).

The change of the groundwater table may be temporary or in extreme cases - permanent. Atmospheric precipitation is the main cause of flooding which causes an increase in the level of surface and underground water (Matusiewicz, 2013; Pawluk, Wrzesiński \& 
Lendo-Siwicka, 2017). If an investment is located near a large reservoir, the level of groundwater may also be affected by the fluctuating water levels in that reservoir (Wrzesiński, Kowalski, \& Miszkowska, 2018). An increase in the number of impervious surfaces related to intensive urbanization may be another reason for flooding. Outflow from hardened surfaces is immediate, while in many cases the existing sewage system is unable to discharge rainwater as the pipe cross-sections are small. Due to this, water accumulates in the lowest areas of the terrain and often stays on the ground surface causing flooding of buildings (Matusiewicz, 2003; Matusiewicz \& Wrzesiński, 2018).

An example of a flooded building is a residential building with an underground garage located in the central part of Poland. The article presents the causes of flooding and analyses the proposed methods for securing underground parts of the building against groundwater which proved to be ineffective and could lead to serious damage to the building. The article used building information modelling (BIM) to provide information about the analysed building and to study the possible hazards arising from the drainage methods applied.

\section{SITE CHARACTERISTICS}

The analysed building is a five-storey residential building consisting of four overground and one underground storeys. The foundation slab of the underground part of the building is at a depth of $2.5 \mathrm{~m}$ below the surface. The building is constructed in a traditional brick technology. The view of the building acquired using BIM technology is presented in Figure 1. In the underground storey, a car park and technical rooms are located (Fig. 2). The building is located in the central part of Poland. It is surrounded by carefully arranged greenery and pine trees growing nearby. To provide information about the analyzed building, Allplan software was used to create the BIM model. BIM technology enabled to study the possible hazards arising from the drainage methods used.

The subsoil of the building consists of fine and medium sands with clay interbeddings. Geotechnical tests required for the preparation of the building project were conducted in 2004 , i.e. in the period characterized by low precipitation. During this period, the groundwater table was located at a depth of about $3.2 \mathrm{~m}$ below the surface. In the geological and engineering documentation, this water level was specified

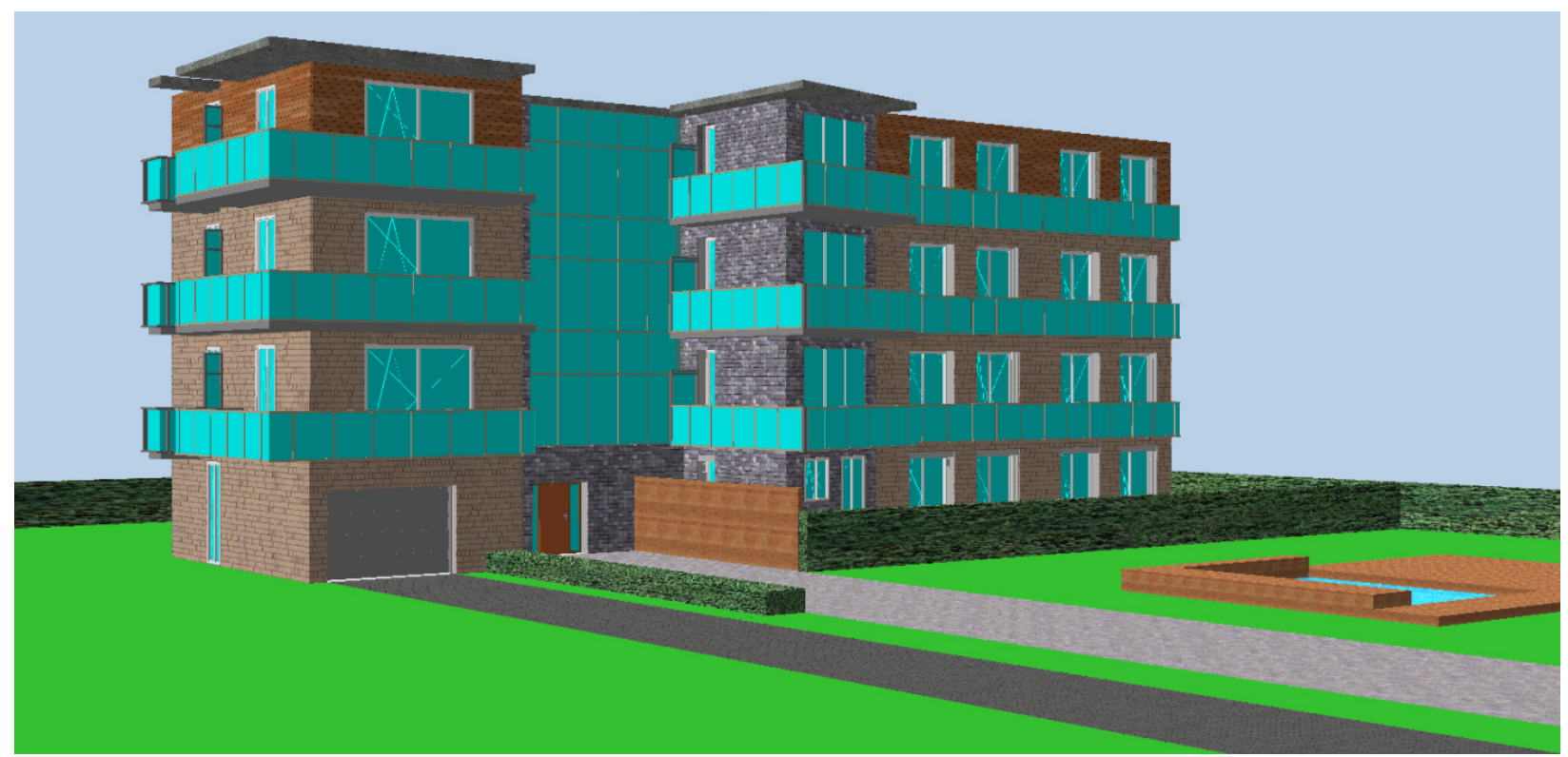

Fig. 1. View of the building acquired with BIM technology 


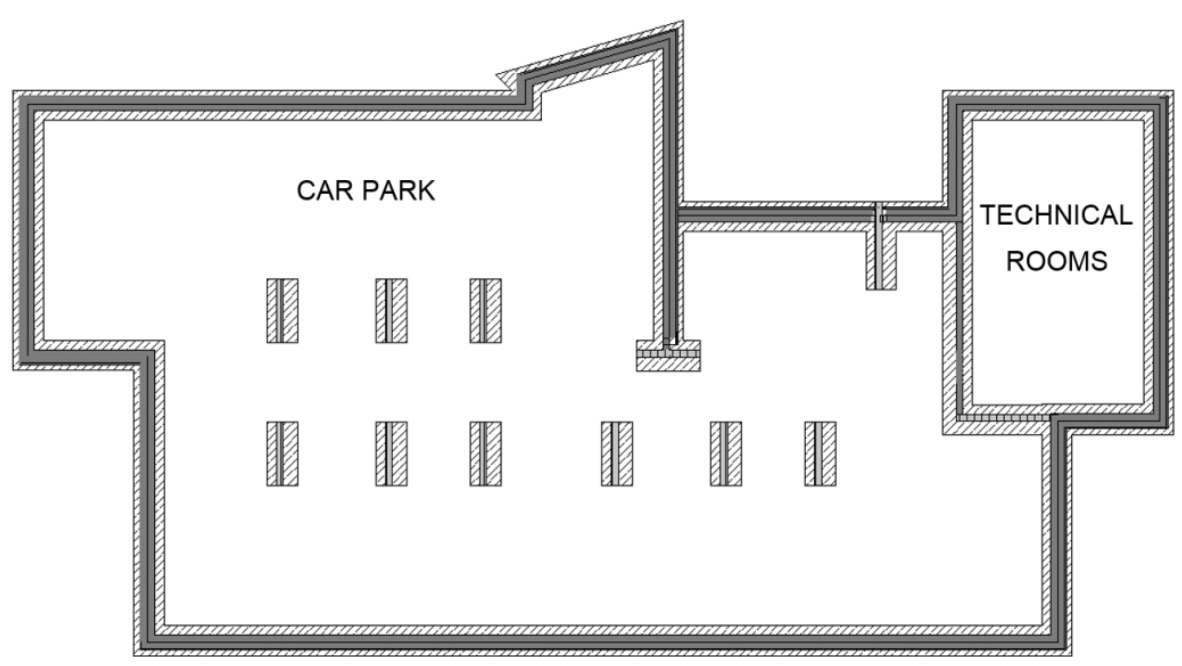

Fig. 2. Level -1 of the analysed residential building

as a reference for the planned project of the building and the possible changes were not taken into account. After a few years of object utilization, the water level increased by about $1.0 \mathrm{~m}$ and the water began to infiltrate the underground part of the building. In some periods, the water level in the underground part of the building rised to $0.3 \mathrm{~m}$ above the floor. Flooding of the underground part of the building rendered the use of the underground car park impossible and caused damage to the technical equipment on level -1 .

\section{METHODS OF DEWATERING}

As a protection method against the groundwater and moisture in the underground part of the building, the developer put a layer of a bituminous material and roofing felt. This method proved insufficient and after the building was used for several years, the water infiltrated the building. The developer then applied external and internal insulation of the building foundations as a protection method. This repair was carried out under the warranty which covered the building for five years from commissioning.

The external insulation of the building foundations was executed in the following way. Initially, the first foundations were excavated from the outside of the building and the old insulation and bituminous material were removed from the foundation walls. Then, the walls were dried. To eliminate rainwater infiltration into the underground floor a concrete slant was made at the connection of the wall with the floor. A layer of extruded polystyrene, felt and bucket foil was applied on the dried wall. Felt, as a multilayer waterproofing material commonly used in construction, effectively protects surfaces against moisture, while the bucket foil complements the felt. A new generation of felt containing bitumen modified with APP plastomer or SBS elastomer was used to protect the foundation against water. Bucket foil was placed on the roofing layer to protect the roofing felt which was exposed to mechanical damage mainly by the roots of trees and plants, as well as to facilitate the sliding of the insulation when the building settled, and thus protect it against damage.

The internal waterproofing was made using mineral waterproofing materials. For this purpose, the underground walls were cleaned from inside and all cavities were filled in. The walls were sealed by applying three layers of a sealing substance. Self-adhesive foil was used to achieve the horizontal waterproofing of the floor plate. Self-adhesive insulation strips were glued to the soil with an overlap of $10 \mathrm{~cm}$. Then a slip layer consisting of two layers of PE film was laid and a protective screed was made. The insulation of the floor slab was led out to the basement walls to seal the connection of the slab with the foundation wall. At 
the junction of the wall with the foundation, a facet of quick-setting mineral sealing material was applied in order to avoid stress in the waterproofing layer. The external and internal insulation of the foundations of the residential building is shown in Figure 3.
Due to the lack of effectiveness of the applied waterproofing, four PVC wells with an internal diameter of $1 \mathrm{~m}$ were constructed (Fig. 4). Holes with a diameter of $0.30 \mathrm{~m}$ were made in the bottom of the wells and on their sides in order to let the water inside the wells.

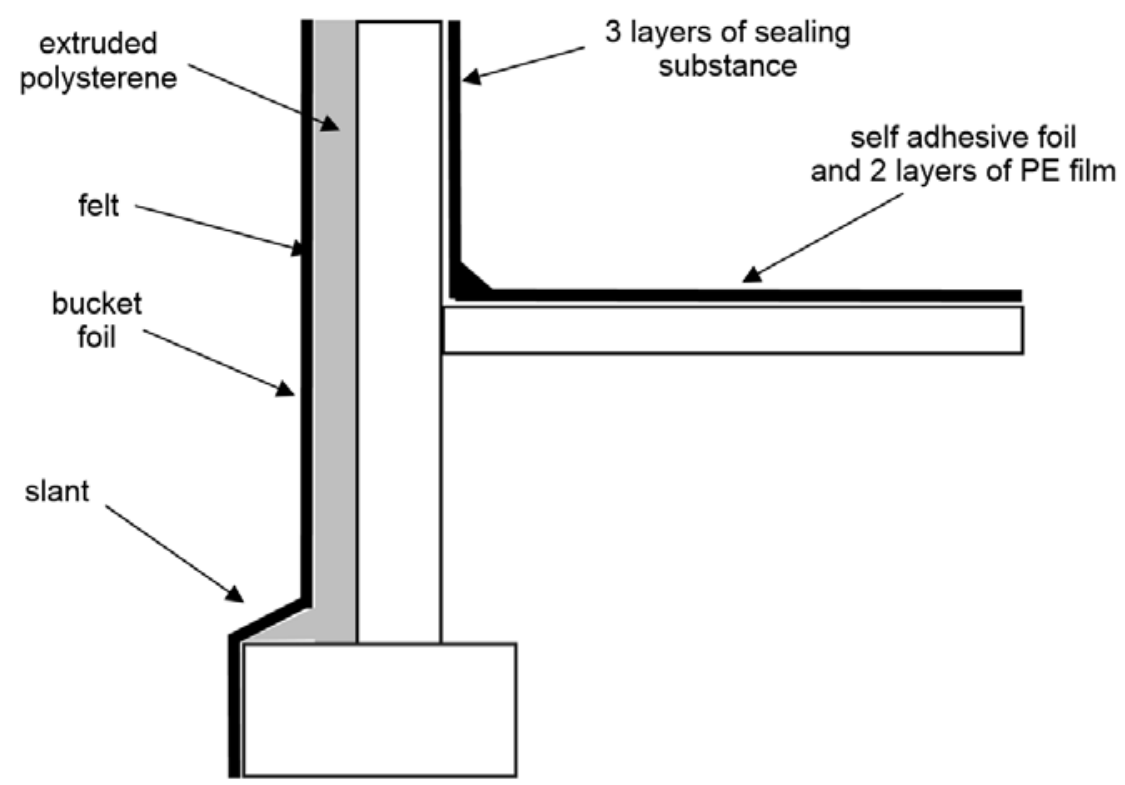

Fig. 3. The external and internal insulation of the foundations of residential building

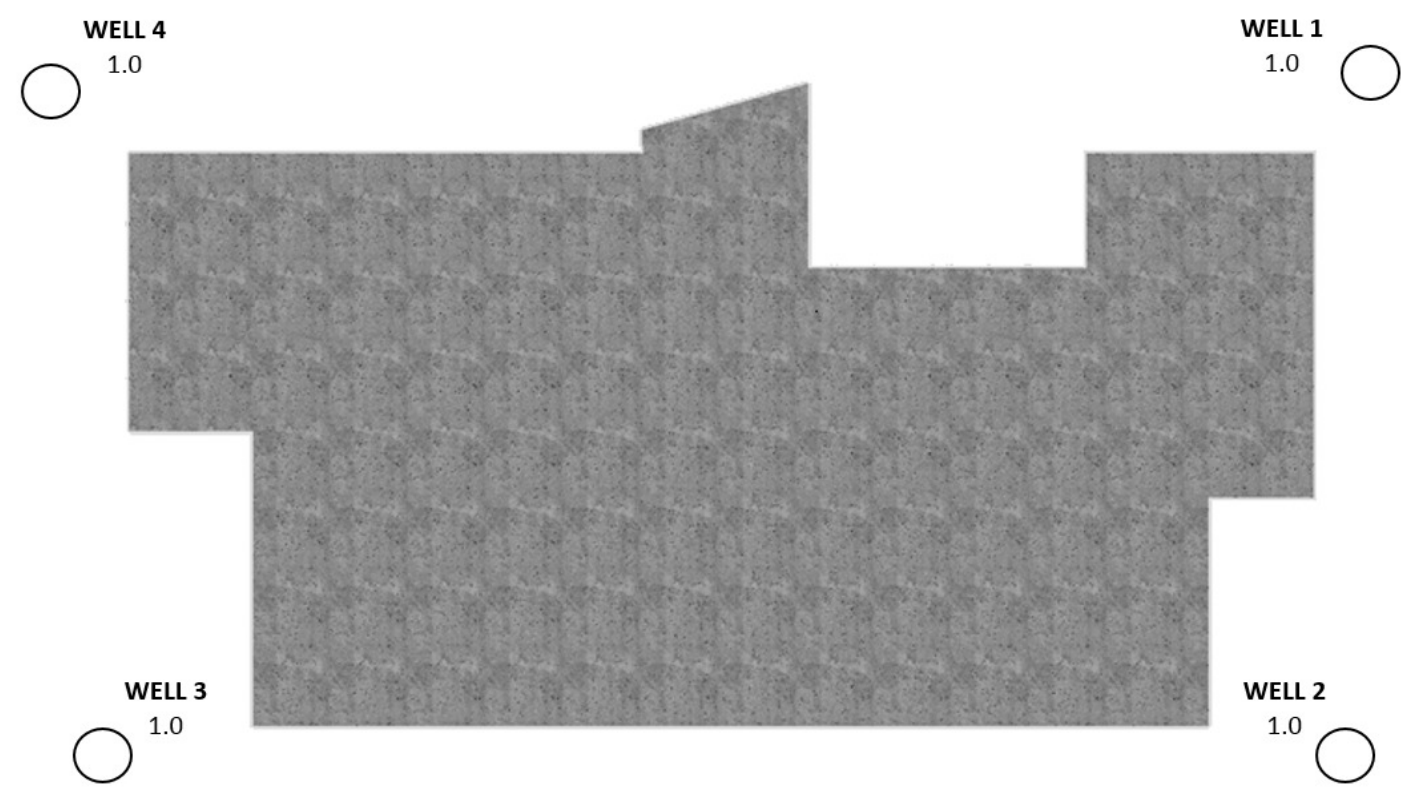

Fig. 4. PVC wells used to lower the groundwater level around the building 
The wells were placed at a distance of $1 \mathrm{~m}$ from the building. From the wells, the water was pumped using submersible pressure pumps into the collective well and further to the storm water drainage system located in the street. This system was activated several times a day when the water began to appear on the floor of the underground part of the building. This reduced the level of the underground water near the building and allowed for normal use of the underground part of the building.

The location of the well in sandy soils and the lack of a filter in the drilled inlet holes of the well caused water and soil to be displaced into the well through the inlet holes. The soil was regularly removed from the inside of the well. After a few years of using the described drainage system, scratches appeared on the foundation slab and one of the outer walls of the building. Experiments conducted showed that the soil near the building was probably loosened over a considerable area. This could lead to a construction disaster. The reason for the loosening was the soil and water getting inside the well. As a result of the actions taken, the PVC wells were removed and the well holes were filled with sand. As a reinforcement procedure for the loosened soil, it was recommended to stabilize the soil around the building by jet grouting method. However, this method was rejected due to the lack of funds. Permanent observations of the settlement of the building were initiated.
The lack of effectiveness of the currently applied methods of securing the underground parts of the building against groundwater led to the search for new methods. Permanent drainage of the building with external ring drainage was proposed. Drainage was carried out at a distance of $2.5 \mathrm{~m}$ from the walls of the building, below the floor of the underground car park. Corrugated PVC pipes with a diameter $(d)$ of $0.113 \mathrm{~m}$ and a width of the inlet gap $(s)$ of $1.5 \mathrm{~mm}$ were used for drainage. The system consisted of four external inspection and sediment drainage wells with a diameter of $0.8 \mathrm{~m}$ and one collective well with a diameter of $1.0 \mathrm{~m}$. Drainage pipes inclination $(i)$ of $3 \%$. The drainage was protected against clogging with a double-layer mineral aggregate filter. The bottom layer adjacent to the filter was compacted aggregate with a fraction of $2 / 8 \mathrm{~mm}$; the upper layer was coarse sand. The filter was selected according to the Abramov method. On the bottom of the trench, below the filter, a geotextile fabric with a filtration coefficient above $25 \mathrm{~m} \cdot$ day $^{-1}$ was laid out. Geotextile fabrics are designed to create a separation layer between the drainage pipe and the subsoil. After completion of the drainage works, the terrain was appropriately shaped to create a slope from the building towards the drainage. The drainage water flows by gravity into the collecting well. Then, it is pumped out from the collecting well into the storm water drainage system located in the street. The external drainage is shown in Figure 5.

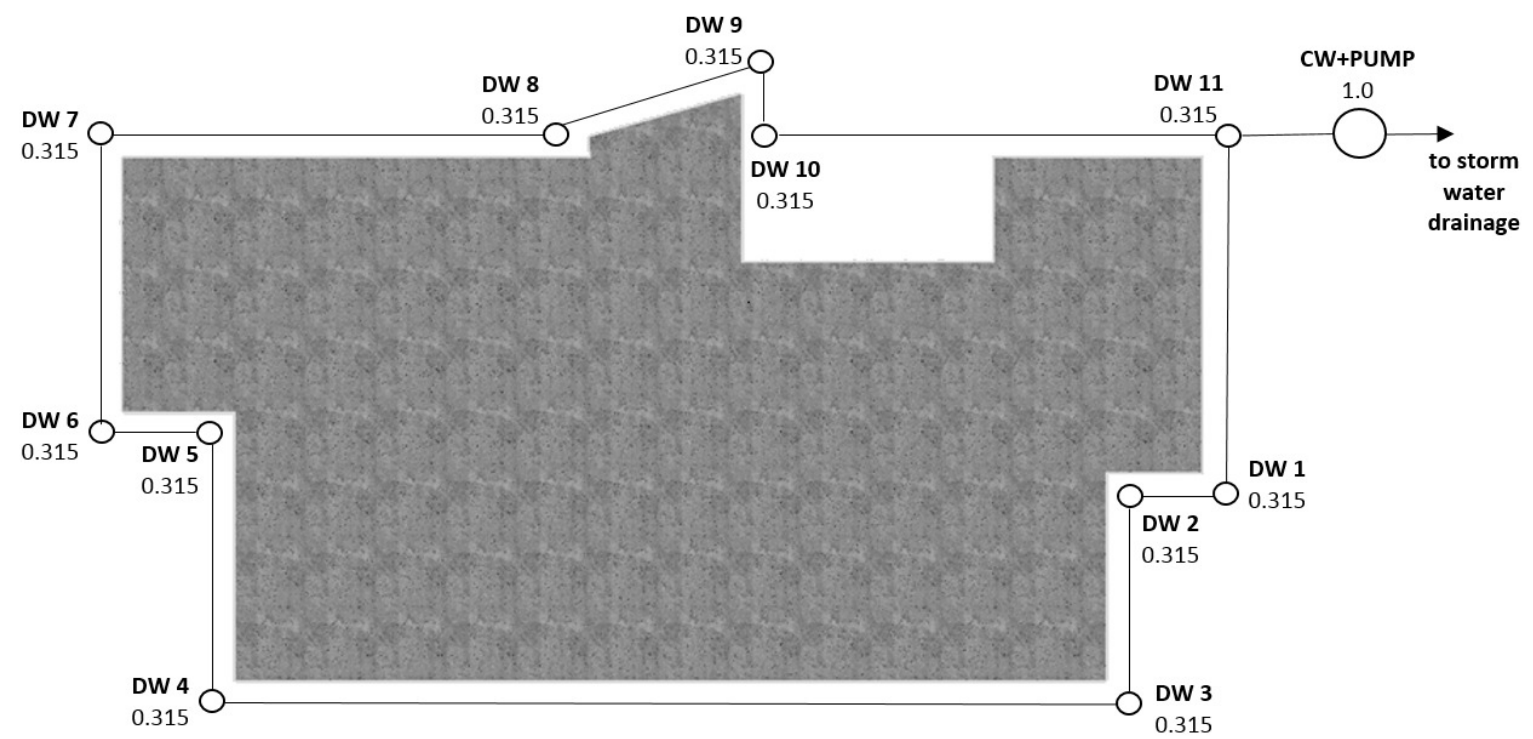

Fig. 5. The external drainage system used to drain the residential building 


\section{ANALYSIS OF THE IMPACT OF THE DRAINAGE METHODS ON BUILDING SAFETY}

While analysing and assessing the impact of the methods used to protect the building against the groundwater, it should be emphasized that the reason behind the incorrectly selected methods was a desire to reduce the costs of the investment. The first mistakes were made at the stage of design since the possible changes in the level of the groundwater table were not taken into account. The underground part of the building was made using a traditional method, i.e. made of brick and protected with a layer of bituminous material and roofing felt. This design solution does not provide protection against groundwater; it only protects against moisture. Water appeared in the underground part of the building for the first time during the warranty period covering the building; therefore the fault was fixed by the developer. The external and internal insulations of the foundations used by the developer were a temporary solution and did not fulfill their function in the event of groundwater retention for a long period. It should be emphasized that the use of temporary solutions by developers during a warranty period is a common practice. Any repairs in this period are made at the minimum cost only to last until the five-year warranty period ends. This approach is also supported by the building management board appointed by the developer which usually works in favour of the developer in the first years of the investment. In the analysed case, securing the underground part of the building through the use of external and internal insulation turned out to be ineffective after about one year of use, i.e. after the warranty expired. It should be highlighted that during the insulation works the level of groundwater was below the foundations. In the event of water appearing in the underground parts of the building, hasty actions are often taken, such as continuous pumping of water from the inside of the building or drilling holes outside the building and pumping the water out. This type of drainage can lead to a construction disaster by leaching and loosening the soil under the building's foundations.

In the analysed case, in order to reduce costs, four wells were made in the corners of the building.
The use of wells caused uncontrolled activation of adverse filtration phenomena near the foundations. A particular threat to the stability of the building was the ill-considered removal of soil extracted from the water to the depression well which was not protected by a filter. The diameters of the inlet holes in the walls of drainage wells exceeded the allowable dimensions by several dozen times. This led to the loosening of the soil at the foundations and the creation of scratches in one of the building walls and the foundation slab. The width of the resulting scratches in the building reached $1.4 \mathrm{~mm}$. The wall and foundation slab with scratches up to $1.4 \mathrm{~mm}$ are presented in Figures 6 and 7. In the analysed investment, the method of lowering the groundwater table using a well could have led to a construction disaster. Cracking of the foundation slab led to faster water penetration into the building, and the underground garage was decommissioned until drainage around the building was made. In the analysed case, it seems reprehensible that an expert opinion on the technical condition of the building was not sought. Instead, only provisional crack protection measures were introduced. The lack of professional subsoil reinforcement, e.g. by using the jet grouting method, also seems unacceptable. The expertise was probably not made due to cost savings, thus exposing the building to future failures.

The use of BIM technology to create a 3D model of the building enabled the provision of information about the building and the analysis of possible threats arising from the used drainage methods. A 3D model illustrated where the largest scratches occurred in the building and whether installations and load-bearing elements of the structure were at risk. The places where the largest scratches were formed are marked in Figures 6 and 7. Analysis of a 3D model shows that there are no building installations at the site of the scratches. However, the gable wall is a load-bearing element of the structure and scratches on its surface may cause threats to the building structure. Scratches of the foundation slab do not affect the load-bearing elements of the building. It is recommended to observe the places where the cracks formed and to take steps in case their width increases. 


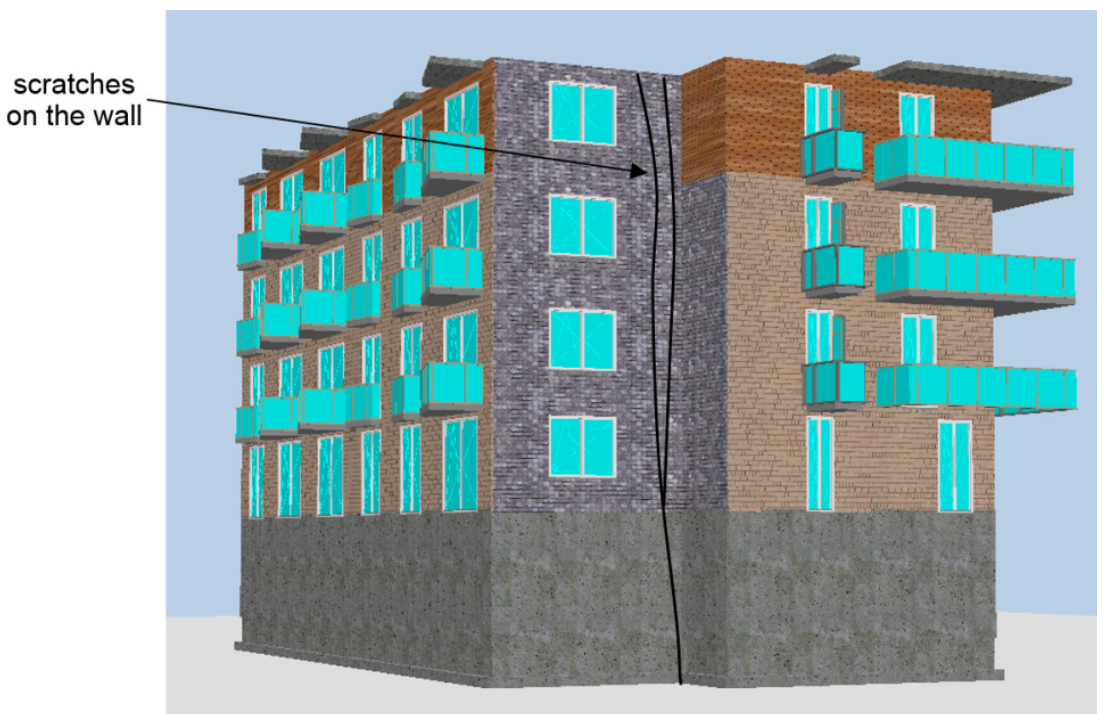

Fig. 6. Wall with scratches up to $1.4 \mathrm{~mm}$ wide

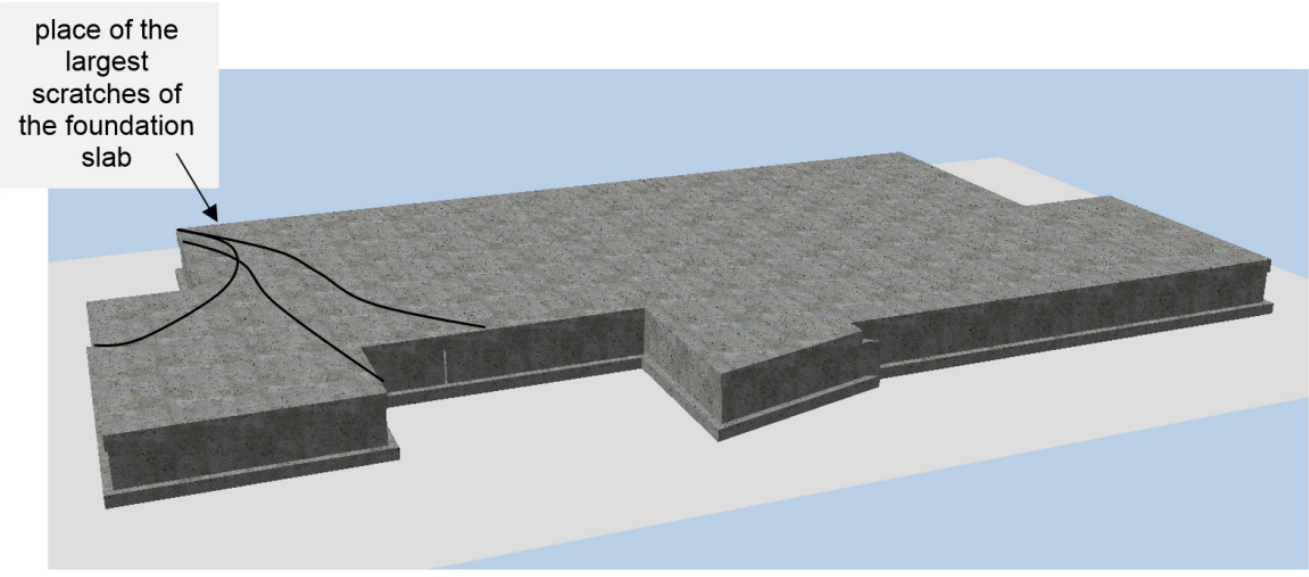

Fig. 7. Slab foundation with scratches

\section{CONCLUSIONS}

The article presents the problem resulting from the changing level of the groundwater table and flooding of the underground part of a residential building with an underground garage. Three solutions were applied to secure the underground parts of a building against the groundwater: external and internal insulation, wells and external drainage. The external and internal insulation turned out to be ineffective in the case of a long-lasting high water table. Pumping water from the wells installed in the corners of the building turned out to be an effective way of lowering the water level, however, it caused uncontrolled activation of adverse filtration phenomena within the foundations. This led to scratches on the walls and the foundation slab of the building. Further lowering of the water level with a well could lead to a construction disaster. After the occurrence of the defects, an external drainage was 
performed, which proved to be an effective way to protect the underground part of the building. However, due to the higher cost of implementation in comparison with the previous methods, it was not previously considered.

The use of BIM technology to create a 3D model of the building enabled the provision of information about the building. Created 3D model illustrated where the largest scratches occurred in the building and whether installations and load-bearing elements of the structure were at risk.

It should be noted that warranty repairs performed by developers are often only temporary in nature and their purpose is to last until the five-year warranty expires. During the period of the first five years after the construction of the building, it is most often managed by persons designated by the developer. Limiting expenses on expert opinions, which would help to understand the causes of threats, and implementation of improper solutions may cause hazards to the construction of buildings and an increase in future costs associated with maintenance of the investment.

The presented example should be a warning to designers, engineers, developers and building managers that the lack of proper recognition of the subsoil and disregard of the symptoms of improper technical solutions that were previously applied may lead to unfavourable and, at the last stage, uncontrolled phenomena threatening the security of the building.

\section{REFERENCES}

Koda, E., Matusiewicz, W. \& Osiński, P. (2017). Niesprawność systemów odwadniających w obiektach budowlanych. In M. Kaszyńska (Ed.), Monografia awarie budowlane: zapobieganie, diagnostyka, naprawy, rekonstrukcje (pp. 411-422). Szczecin: Wydawnictwo Uczelniane Zachodniopomorskiego Uniwersytetu Technologicznego w Szczecinie.

Matusiewicz, W. (2003). Performance of storm water system in urban catchment under conditions of heavy rainfall. Acta Sci. Pol. Architectura, 2 (2), 83-96.

Matusiewicz, W. (2011). Safety abatement of building foundation caused by incorrect method of dewatering. Scientific Review - Engineering and Environmental Sciences, 20 (4), 344-354.
Matusiewicz, W. (2013). Foundation walls drying and dewatering of soil adjacent to the Ursyn Niemcewicz Palace. Scientific Review - Engineering and Environmental Sciences, 22 (2), 208-221.

Matusiewicz, W. (2015). Dewatering of sanitary installations located under building basement. Scientific Review - Engineering and Environmental Sciences, 24 (3), 286-300.

Matusiewicz, W. \& Wrzesiński, G. (2018). Drainage of the depression area in a small urban catchment. Acta Sci. Pol. Architectura, 17 (3), 131-144. doi: 10.22630/ ASPA.2018.17.3.35

Mielcarzewicz, E. (1971). Melioracje terenów miejskich i przemystowych. Warszawa: Arkady.

Patel, A. (2019). Geotechnical Investigations and Improvement of Ground Conditions. doi: 10.1016/B978-0-12817048-9.00004-4

Pawluk, K., Wrzesiński, G. \& Lendo-Siwicka, M. (2017). Strength and numerical analysis in the design of permeable reactive barriers. IOP Conference Series: Materials Science and Engineering, 245, 1-8.

Thomas, S., Goodfellow, T. \& Watson, J. (2019). Groundwater Recharge Systems to Mitigate the Impact from Construction Dewatering. In J. Monteiro, A.J. Silva, A. Mortal, J. Aníbal, M. M. da Silva, M. Oliveira \& N. Sousa (Eds.), INCREaSE 2019. Proceedings of the 2nd International Congress on Engineering and Sustainability in the XXI Century (pp. 757-765). Cham: Springer.

Todd, D. (1980). Groundwater Hydrology. 2nd ed. Chichester: John Wiley \& Sons.

Wrzesiński, G. (2020). Permeability coefficient tests in non-cohesive soils. Scientific Review - Engineering and Environmental Sciences, 29 (1), 72-80. doi: 10.22630/ PNIKS.2020.29.1.7

Wrzesiński, G., Kowalski, J. \& Miszkowska, A. (2018). Numerical analysis of dewatering process of deep excavation. In 18th International Multidisciplinary Scientific GeoConference (SGEM 2018): Hydrogeology, Engineering Geology and Geotechnics. Science and Technologies in Geology, Exploration and Mining Conference Proceedings. Issue 1.2 (pp. 497-504). Sofia: International Multidisciplinary Scientific GeoConferences (SGEM).

Zaborova, D. D. \& Petrichenko M. R. (2018). Technology of rapid dewatering for excavations. In M. A. Ali \& P. Platko (Eds.), Advances and Trends in Engineering Sciences and Technologies III (pp. 663-668). London: CRC Press. doi: 10.1201/9780429021596 


\section{ZAGROŻENIA WYNIKAJĄCE Z ZASTOSOWANIA NIEPRAWIDŁOWEGO SYSTEMU ODWODNIENIA BUDYNKU Z WYKORZYSTANIEM BIM}

\section{STRESZCZENIE}

Artykuł dotyczy zagrożeń wynikających z niewłaściwego zastosowania metod zapobiegających podtapianiu wodą gruntową części podziemnych budynku na przykładzie budynku mieszkalnego wielorodzinnego z garażem podziemnym. Po kilku latach użytkowania budynku w garażu podziemnym zaczęła pojawiać się woda gruntowa. Zastosowano zabezpieczenia mające ograniczyć dostawanie się wody do wnętrza obiektu, które okazały się nieskuteczne. Wykorzystanie w niewłaściwy sposób studni do obniżenia poziomu wody gruntowej wokół budynku doprowadziło do powstania znacznych zarysowań na ścianach zewnętrznych oraz płycie fundamentowej. W artykule wykorzystano building information modelling (BIM) w celu dostarczenia informacji o analizowanym budynku oraz przeanalizowania możliwych do wystąpienia zagrożeń wynikających ze stosowanych metod odwodnienia.

Słowa kluczowe: odwodnienie, drenaż, studnia, uszkodzenia budynku, woda gruntowa, BIM 